\title{
Improving Student Readiness: Examining K-16 Alignment of Content and Performance Standards
}

\author{
Dean M. Beaubier \\ Elton Collegiate Institute
}

Student readiness continues to be an issue among the professoriate (Cramer, 2010; Greenberg, 2010; Kelley, 2010). Enrolment growth trends in Canadian universities suggest this concern may remain prevalent for some time (Overall, 2011). At the secondary level, government bodies have developed and implemented policies and standardized assessment instruments with the expressed means of improving accountability and student academic proficiency. Despite these efforts, there does not appear to be a perceived change in the readiness of students attending tertiary institutions. The purposes of this study were to determine the current state of alignment between high school and university learning outcomes and assessment standards, and outline policies/factors that would establish or strengthen this alignment.

\section{Introduction}

$\mathrm{R}$ ecent challenges to the Canadian economy have sparked debate about how the country can remain competitive in global markets. One school of thought suggests the nation must move its attention from developing a workforce centred on manufacturing to one that concentrates on producing jobs related to a knowledge economy. In other words, the emphasis must shift from the 'construction' of items to the 'creation' of ideas. This learning places considerable importance on having a workforce educated beyond the secondary level. Some speculate possessing an undergraduate degree in the future will be the equivalent qualification of a high school diploma in the 1970s as an entry level credential (University of Toronto, 2008). This growing belief that a greater degree of our populace needs higher education is reflected in the escalated enrolment at tertiary institutions (Statistics Canada, 2010).

Driving this increase is a youth cohort under the age of 22, and, for this reason, many universities focus their programming on the needs of younger students who pursue university study either directly from secondary school or very soon thereafter (Association of Universities and Colleges of Canada, 2007). However, with this steady rise in attendance (and potential expansive ability range), specific concerns have come to light centering 
on student readiness and the issue of alignment between secondary and university education systems (Business Council of Manitoba, 2011). Student readiness can be defined as the level of preparation a student needs to succeed - without remediation - in a credit-bearing course at an institution that offers a baccalaureate degree or transfer to a baccalaureate program (Conley, 2007). Difficult transitions for students entering higher education have prompted researchers to urge educators, policymakers, and politicians to think about learning within the context of a K-16 framework. In doing so, a greater sense of alignment between learning outcomes and assessment standards may be fostered in the present dichotomy that arguably exists between secondary and higher education.

\section{Purpose and Method}

Assuming alignment issues are indeed a contributing factor to student readiness, my study examined connections between secondary education curriculum outcomes (content standards) and the evaluation of knowledge and skills (performance standards) pertaining to them. The relationship between these standards and those delineated by a single postsecondary institution were then determined. In particular, I examined the subject of English Language Arts (ELA) to determine alignment between secondary and university standards within the province of Manitoba. This examination included analysis of provincial curriculum/evaluation documents and course outlines, along with input from five subject area secondary teachers and three university professors.

At the secondary level the document analysis included examination of provincial ELA curriculum outcomes (content standards) and the evaluation methodology in recent (2009-2011) provincial examinations (performance standards). These elements were compared to professors' course syllabi and major assignments identified by a former university English department chair. Additional information gathered through interviews with these high school and university teachers addressed the means by which they determined content standards, appropriate measurement instruments and items, and relevant performance standards.

\section{Results}

A major finding was that problems pertaining to readiness might have stemmed from differing objectives and means of assessment that existed between the two levels of education. In the interviews, secondary teachers expressed the challenges related to balancing instruction within six focus areas of language arts. The curriculum documents defined these areas as: listening and speaking, reading and writing, and viewing and representing (Manitoba Education and Training, 2000). The high school teachers also found it difficult to create unit and lesson plans that covered the entire range of learning outcomes. Document analysis of the province's curriculum framework outlined five general learning outcomes and 56 specific outcomes that teachers were expected to teach and assess. In contrast, at the post-secondary level, the English department chair indicated their faculty focused on developing and evaluating students' critical thinking skills and language use primarily through essay writing. General and specific learning outcomes were not specifically articulated in course syllabi distributed by the professors. Instead the syllabi often focused on course descriptions, assignment types, and grading weights. Generally, the evaluation was comprised of major essays presented three times during the academic year and a final essay form examination at the end of the course.

There were also differences in terms of what was considered 'student proficiency' according to the level of study - secondary to post-secondary. Whereas secondary ELA teachers were cognizant of content standards or outcomes, their awareness of, and ability to construct, performance standards was not as evident. High school teachers could access two provincial documents that discussed the latter standards. The earliest of these writings, entitled Rethinking Classroom Assessment with Purpose in Mind (Manitoba Education and Training, 2006), provided limited explanation as to how performance was specifically determined. The document 
only mentioned that alignment was a concern: "Curriculum, assessment, instruction, and learning are interconnected and interact in an iterative and sometimes (but not always) cyclical process. All four need to be aligned and coherent for the learning to be effective and meaningful" (p.15).

A second provincial publication, Communicating Student Learning(Manitoba Education and Training, 2008), offered classroom teachers slightly better insight to the establishment of performance standards by explaining that "the basis for grades must be derived from the learning outcomes" (p.25) and citing the use of criterion-referenced standards so both educators and learners would understand "why 'good' is good and describe what competency looks or sounds like" (p.26). Teachers were encouraged to develop criteria that described performance standards that fit into levels of proficiency. It was explained that while two levels, meeting and not meeting expectations, seemed to make sense, it was important to design rubrics that expanded to four levels.

The teachers' theoretical knowledge towards the establishment of performance standards appeared to be scant. A number of those educators interviewed explained that their understanding of performance standards came not from theory but through their actions as actual practitioners in grading provincial standardized examinations.

In contrast to the secondary emphases, at the post-secondary level the emphasis was on 'high standards' and 'rigorous expectations.' However, there was a lack of uniformly developed or utilized content and performance standards within a department. In other words, standardization of their expectations was absent. There also was an expressed sense of professional 'independence' with regard to assessment methods. In fact, it was noted that the determination of what constituted a letter grade of 'A, $\mathrm{B}, \mathrm{C}$, etc.' in relation to the cut-off scoring percentile range differed among English department professors.

\section{Discussion}

This disjuncture between both content and performance standards found between secondary and higher learning may be due to the fact secondary education historically has involved a student body whose range of academic abilities varies greatly in comparison to the sub-set typical of learners in universities. Given this population variance, secondary education traditionally has focused on creating suitable content standards. Thus, the subsequent performance standards also may be intended more for determining minimum competencies addressing our society's vocational pluralism.

The findings suggested that Manitoba high schools and universities need to determine common ground for the creation of content and performance standards. Notably, they need to establish what is meant by performance considered to be 'proficient' and what criterion reflects such a term. Prior research shows that the process of creating performance standards and attaching labels indicating the student's level of performance is an arduous task beset with technical difficulties and political controversies (Cronin, Dahlin, Adkins, \& Kingsbury, 2007; Hamilton, Stecher, \& Yuan, 2008; Linn, 2003). It may be that teachers and the professoriate require better training with regards to these practices. The problem is that the environments are 'substantially' different. One emphasizes conforming to prescribed documents; the other has at its foundation 'academic freedom' that is reflected in the diversity of expectations and syllabi. The result is a strong disconnect between expectations that students must meet from one level of education to the next. This difficulty does not change the fact that high school teachers are not always sure how to assess and university faculty appear to use essay writing as a primary method for assessment.

Because Manitoba universities do not have entrance examinations such as an ACT or SAT, there also appears to be a need for funding and expert work towards research on the predictive validity of provincial standards and determinants of university success. Additionally, the growth of Manitoba high school Advanced Placement and International Baccalaureate programs and their espoused postsecondary transitional success for students should be examined. It would be important to learn what differences (e.g., student characteristics, 
curriculum objectives, teaching materials, teacher characteristics) exist between such programs and general education courses and any potential impact these differences may have.

Some universities in North America and Europe have attempted a complex approach to standard-setting, involving both the criterion referencing of students' performances and consideration of statistical information about the grade distribution (Baird, 2011). It appears that postsecondary institutions are mindful of establishing elements of consistency and implementing standardized practices when it comes to teaching and evaluating students as evident by the scholarly research recently produced (Choy \& Lidstone, 2011; Cizek \& Bunch, 2007; Harman \& McDowell, 2011; Yorke, 2011). Manitoba's institutions of higher learning should be aware of the issues and trends surrounding assessment and consider the practices and policies discussed and implemented in both secondary and tertiary learning. In establishing this overall goal educators and learners will have greater understanding of expected outcomes between the two levels of education.

\section{Policy Recommendations}

Based on the conclusions, a number of policy recommendations resulted from the study. To begin with, the content and evaluation criteria of all first-year university courses should be examined in relation to their comparative high school subjects. A second policy initiative related to this concern aims at the establishment of a provincial government committee to determine the means and degree to which alignment may be established. Government involvement at this level is necessary for various reasons. This bureaucracy contains individuals who have operational knowledge pertaining to the two systems. These people may be able to identify where gaps exist and determine ways for transitioning students to bridge these gaps. Finally, teacher education pre-service and in-service programs should be developed so that curriculum and teaching methods ensure professionals can prepare students to meet new standards. At tertiary institutions, centres of teaching enhancement need to undertake this same goal with regard to faculty members.

\section{References}

Association of Universities and Colleges of Canada. (2007). Trends in higher education. Retrieved from http://www.aucc.ca/_pdf/english/ publications/trends_2007_vol1_e.pdf

Baird, J.A. (2011). Why do people appeal higher education grades and what can it tell us about the meaning of standards? Assessment in Education: Principles, Policy, and Practice, 18(1), 1-4.

Business Council of Manitoba. (2011). Submission to Minister Wowchuk in preparation for the 20112012 budget. Retrieved from http://www. businesscouncil.mb.ca/images/Publications/ FiscalCompetitive/2011 fiscalissuessubmissi on.pdf

Choy, S. \& Lidstone, J. (2011). Grading: Harmonizing standards and stakeholder expectations. Quality in Higher Education, 17(1), 111-115.

Cizek, G.J. \& Bunch, M.B. (2007). Standard setting: A guide to establishing and evaluating performance standards on tests. Thousand Oaks, CA: Sage.

Conley, D.T. (2007). Redefining college readiness. Retrieved from https://www.epiconline.org / files/pdf/RedefiningCR_Vol3.pdf.

Cramer, S. (2010). Students failing language exams: Universities concerned about growing grammar problems. Retrieved from http:// www.mcgilltribune.com/2.12329/studentsfailing-language-exams-1.1626277

Cronin, J., Dahlin, M., Adkins, D., \& Kingsbury, 
G.G. (2007). The proficiency illusion. Washington, DC: Thomas B. Fordham Institute.

Greenberg, A. (2010). We don't need no education: How the bright minds of tomorrow managed to side-step the English language's most basic rules. The Queen's Journal. Retrieved from http:/queensjournal.ca/story/2010-02-09/ postscript/we-dont-need-no-education/

Hamilton, L.S., Stecher, B.M., \& Yuan, K. (2008). Standards-based reform in the United States: History, research, and future directions. Retrieved from http://www.rand.org/pubs/ reprints/2009/RAND_RP1384.pdf

Harman, K. \& McDowell, L. (2011). Assessment talk in design: The multiple purposes of assessment in HE. Teaching in Higher Education, 16(1), 41-52.

Kelley, S. (2010, February). Texting, twitter contributing to students' poor grammar skills, profs say. The Globe and Mail. Retrieved from http://www.theglobeandmail.com/news/ technology/texting-twitter-contributingto-students-poor-grammar-skills-profs-say/ article $1452300 /$

Linn, R.L. (2003). Performance standards: Utility for different uses of assessments. Education Policy Analysis Archives, 11, 31.

Manitoba Education and Training. (2000). Senior 4 English language arts: Manitoba curriculum framework of outcomes and senior 4 standards. Retrieved from http://www.edu.gov. mb.ca/ $\mathrm{k} 12$ /cur/ela/docs/s4_framework/s4_ fulldoc.pdf

Manitoba Education and Training. (2006). Rethinking classroom assessment with purpose in mind. Retrieved from http://www.edu.gov. $\mathrm{mb} . \mathrm{ca} / \mathrm{k} 12 /$ assess/wncp/rethinking_assess_ mb.pdf
Manitoba Education and Training. (2008). Communicating student learning. Retrieved from http://www.edu.gov.mb.ca/k12/assess/ docs/csl/csl_doc.pdf

Overall, C. (2011). University for the masses may be oversold. University Affairs. Retrieved from http://www.universityaffairs.ca/universityfor-the-masses-may-be-oversold.aspx

Statistics Canada. (2010). University enrolment by registration status, program level and gender. Retrieved from http://www.statcan.gc.ca/ daily-quotidien/100714/t100714a1-eng. htm

University of Toronto. (2008). Towards 2030: Planning for $U$ of $T$ 's future. Retrieved from http://www.towards2030.utoronto.ca/files/ towards-2030-sec 2 .pdf

Yorke, M. (2011). Summative assessment: Dealing with the measurement fallacy. Studies in Higher Education, 36(3), 251-273.

\section{Biography}

Dean Beaubier is a high school classroom teacher who holds a doctoral degree in Education Studies from the University of Nebraska-Lincoln. His interests include equity issues, policy planning, and concerns surrounding assessment. He can be reached at dbeaubier@rrsd.mb.ca. 